\title{
THE FORMATION OF THE GREEN BUILDING MARKET OF THE RUSSIAN CITIES
}

\author{
Ekatarina Gennadievna Pahomova* \\ Southwest State University, Kursk, Russia \\ Vladimir Ivanovich Tomakov \\ Southwest State University, Kursk, Russia \\ Maksim Vladimirovich Tomakov \\ Southwest State University, Kursk, Russia
}

The article discusses basic directions of construction sector development in modern ecological conditions, principles of sustainable development of cities and the problems hindering imple-mentation of green building principles in the Russian Federation. The article indicates the most promising concept of a building complex development which is the construction in compliance with environmental standards (green building). The peculiarities of green building in Russia are considered and the reasons for its slow development are revealed. The reasons hindering large-scale application of green construction standards are discussed. The methods of the gov-ernment incentives for green technologies market in Russia are proposed.

Key words: Sustainable development concept, Cities sustainable development, Environment, green building, Green standards

\section{INTRODUCTION}

Sustainable development of a city provides residents-safety and high living standards while conserving natural environment, resources and maintaining ecological balance in economic and social life of the citizens. Hence, transition of cities to the principles of sustainable development requires a complex approach to solve the problems of urban planning activities. Almost the whole city-forming policy during rapid growth of the cities in Russia in the $20^{\text {th }}$ century was carried out without sufficient consideration of environmental factors, conservation and recovery of the natural environment to improve living standards. As a result, excessive con-sumption of energy and natural resources caused high levels of urban chemical, biological and physical pollution. This situation was due to the fact that, until recently, basic principles of state policy in the field of environmental protection during construction of any immovable property poorly motivated the workers of this industry to implement green technologies for the following reasons:

1) The cost of energy resources in Russia is 2-4 times lower than in Europe; as a result, both a manufacturer of green building products and their end users are not economically in- terested in energy-efficient technologies;

2) There is no real government support, for example, in the form of tax incentives for real estate developers, actively and comprehensively implementing the principles of green building in their activities;

3) The representatives of state examination, understanding the necessity for implementing green technologies in modern construction, often claim to exclude them from the project due to their lack in current regulations [1];

4) The majority of the consumers of construction products do not have a clear understanding of ecological construction yet, so 'smooth walls and ceilings' are much more significant for them than energy efficiency when renting or purchasing property;

5) Russian developers are seeking to build a facility with less material and time costs, developing a project for 10-15 years ahead, entering into rental agreements for this period or selling buildings immediately after construction. However, such narrow terms negatively affect the investment attractiveness of green technologies.

Russia continues to be the state in which traditional technologies of design and construction 
of objects of immovable property as well as assessment of their impact on the environment are used. As a result construction facilities continue to consume $40 \%$ of primary energy, $67 \%$ of electric energy, $40 \%$ of raw materials and $14 \%$ of pure water [2]. According to the researches, it is possible to save $25-30 \%$ of energy by improving the energy efficiency of the existing buildings and buildings under construction. All these factors indicate that it is absolutely necessary to transit to green building in practice in the sphere of construction in Russia.

\section{EFFICIENCY "GREEN TECHNOLOGY”}

In recent decades Russia has been making efforts to fit the cities into the natural environment. Transition of urban community to the implementation of the principles of sustainable development provides the basis for environmental problems solution. In this case, green building can be considered as a mechanism for the sustainable development of urban territories and solving environmental problems. Although green technologies are new and not the easiest direction of progress, they demonstrate high efficiency.

For example, when DPR Construction Company planned to build an office in California (USA), its experts have calculated the costs necessary to get scores according to American system of building assessment - Leadership in Energy and Environmental Design (LEED) as well as the cost of building operation. According to the survey $\$ 85,000$ were necessary for green technologies implementation but within ten years, the company can save $\$ 400,000$ for operating costs [03].

Green buildings have less negative impact on the environment than conventional buildings. This is achieved by means of more efficient and rational use of resources, use of alternative re-sources for the conservation of natural ones, and waste utilization. Thus, widespread practice of green building can be one of the most effective tools of sustainable development of the society. Primarily, green buildings are designed to save energy and water consumption which can be reduced by an average of $25-30 \%$ and $30-50 \%$, respectively. There are many studies which prove that green buildings design and construction costs differ slightly from those of conventional buildings. For example, the studies have shown that on average the cost of construction of 33 green buildings in Massachusetts (USA) is by only $2 \%$ higher; the study of more than 150 buildings, which received a minimum rating according to American system of assessment of buildings in the United States, showed that the construction of such a building is only by $0.8 \%$ more expensive to build than a conventional buildings on average [04].

A green building can influence on the increase of workers and staff's labour efficiency without any negative impact on their health due to the use of building materials which do not produce harmful emissions. Good daylight penetration, individual climate control and good visual envi-ronment also factor into the performance. Improving the quality of air indoors increases produc-tivity and reduces the loss of working days for health reasons. Studies conducted in the United States show that increase in productivity by $1.5 \%$ is equivalent to $\$ 1,000$ a year or to $\$ 4-5$ per $1 \mathrm{~m}^{2}$. It was calculated that financial advantages of the building, which has LEED's silver certificate, is $\$ 35$ per $1 \mathrm{~m}^{2}$ [5], and this is only due to increase in productivity.

Currently, in the United States the share of green buildings among all new-built constructions has already reached $20 \%$. In the construction sector of the EU countries, the data are almost the same. The number of certified buildings in the developed countries is constantly growing.

The convincing examples of the successful implementation of green projects are: "Green Lighthouse" - a building in the center of Copenhagen (Denmark has not only a healthy climate, but also extremely low energy consumption); "Grimaldi Forum Monaco" in Monaco; "Manitoba Hy-dro Place", Winnipeg, Canada; the building of the Law Faculty of the University of Sydney in Australia; "Crowne Plaza Copenhagen Towers" - a 25-storey hotel in Copenhagen, self-sufficient in electricity from renewable sources; "Green Towers" - refurbished building, in which the headquarters of Deutsche Bank is placed in Frankfurt; California Academy of Sciences; Sidwell Friends School (Washington, DC), Hearst Tower skyscraper and the building of Bank of America Tower in New York (USA) etc. In London there are whole blocks of residential build-ings, which were built applying highly energy-efficient technologies, for example, Greenwich Mil-lenium Village and BED ZED. There is a 'sunny' village Solarsiedlung am Schlierberg in Freiburg (Ger- 
many), a block of buildings with solar panels in Helsinki (Finland). In Western countries, there are a number of examples of successful implementation of the principles of green construction approved by the governments of the states.

\section{THE TRANSITION TO PRACTICE APPLICATION OF THE PRINCIPLES OF "GREEN BUILDING"}

Green standards are designed to accelerate the transition from conventional design and construction of buildings and structures to sustainable one, which complies with the following principles:

- safety and favourable conditions for healthy human life;

- minimized negative impact on the environment;

- consideration of the interests of future generations.

Green standards consider the full cycle of energy expended in the design, construction, opera-tion, utilization and recovery. A complex economy in the framework of at least six project sec-tions such as land, water, energy and atmosphere, materials and resources, internal environment quality, and innovation is understood as energy in this paper.

Currently, there are two well-known leaders both in the international and Russian markets of green certification [6]: BREEAM (UK) and LEED (USA). German DGNB [7] is considered a local rating system so it is not popular in Russia. This group includes all national standards, such as the HQE (France), EcoProfile (Denmark), CASBEE (Japan), GBI (Canada), Green Star (Australia).

The American LEED system [08] is focused on energy efficiency, innovations in design, operation and social aspects.

The British BREEAM system (Building Research Establishment Environmental Assessment Method) evaluates the quality of construction, building materials and infrastructure [09].

There are several reasons for choosing BREE$A M$ and LEED green methods of certification Russian. These standards have been adopted as national standards in many countries and formed the basis of the national ranking systems. The number of facilities certified according to these standards is high when compared to other rating systems; these standards are the most commonly used in all countries. BREEAM method assesses sustainability of a building at two stages: at the design stage, it is possible to get intermediate International New Construction cer-tificate, and at in-use stage, it is possible to get a final BREEAM In-Use certificate [10]. BREEAM is the first rating and assessing method of buildings and structures in the world. Using this method 200,000 buildings are certified and more than a million ones are registered for assessment.

Russia's first national green standard is GOST R 54964-2012 "Conformity assessment. Eco-logical requirements for estate properties". It contains regulations concerning reduction of energy consumption, construction of artificial lakes next to green facilities, bicycle parkings and charging stations for electric vehicles and hybrid cars, etc.

This standard is developed taking into account the experience of the international BREEAM and LEED systems of certification, setting environmental requirements for buildings and structures; it can be used at all stages of the facility's life cycle (design - construction - refurbishment). The main objective of the standard is to set benchmarks of environmental requirements in construc-tion for all participants of the construction process: from a customer and a developer to builders.

GOST R 54964-2012 is the first official State Standard for Green Building which highlighted the need for an integrated approach to the assessment of project sustainability, considering the whole life cycle of facilities, professional management and the involvement of specialists in the field of green construction; it also introduced a number of promising areas (cleaning and utiliza-tion of greywater, reducing energy consumption by 30 to $60 \%$ as compared with the defined baselines).

Introduction of the national standard for green building assessment of real estate facilities will make it possible to follow the principles of sustainable development.

Taking into account the global experience of buildings certification, it can be affirmed that using national standard facility's investors, developers and owners are able to increase the competi-tiveness and marketing appeal of the project due to the reduction of future operating costs, min-imizing the impact on the environment and people, improving the quality of working and liv- 
ing environment, as well as the compliance of the facility with the standard, which, demonstrating a commitment to environmental goals, allows the company to be publicly called a green company [11]. Considering the fact that the statutes of a number of major international commercial com-panies (e.g. IKEA) contain provisions according to which they have to rent or buy only green offices in whatever country they may be, the benefits for developers from the introduction of new green standard are obvious.

Some developments of the Ministry of Natural Resources and Environment of the Russian Federation are worth noticing. They include the "Green Standards" system, which was later replaced by RUSO (rating system of assessing the sustainability of the environment). In addition, in the Russian market there are the standards developed by NP "AVOK" and the National Association of Builders: STO 2.35.4 "Green Building. Residential and Public Buildings. Rating System of Assessing the Environmental Sustainability" and STO 2.35.68 "Green Building. Considerations on Regional Peculiarities in the Rating System of the Environmental Stability".

The main advantage of national standards is that they are fully adapted to the Russian regulatory framework, take into account climatic factors, and technologically and financially accessible.

Green construction in Russia emerged much later than in the EU or the USA and is taking its initial steps. However, the state is actively spurring the construction industry into this direction and in the future, these activities will be enhanced.

Thus, in April 2012 in the Russian Federation "Basic Principles of State Policy in the Field of Environmental Development of the Russian Federation for the Period up to 2030" were approved; they shall ensure environmental safety in the period of economy modernization and in the process of innovation development. The documents make provision for comprehensive measures (mechanisms) that will allow Russian construction industry to come as close as pos-sible to international standards and practice of green construction in the next 10-15 years. These measures include:

1) Creation of a coherent and consistent system of legislation in the field of environment conser-vation through adoption of new regulatory legal acts to meet up-to-date requirements of the de-velopment of the society, including the construction industry;

2) Joint participation of the state, business community, public-governmental organizations and research organizations in the implementation of energy-efficient and environmentally friendly technologies which will allow creating a competitive and environmentally-oriented model of eco-nomic development;

3) Improvement of procedures and methodologies for assessment of impacts on the environ-ment;

4) Implementation and harmonization of international environmental standards;

5) Increase in the construction of buildings and structures taking into account international expe-rience in the application of green standards;

6) Research work in the field of forecasting environmental threats as well as the development and utilization of the science-based indicators of environmental impact;

7) Formation of environmentally responsible worldview at all levels of the society by means of the state support of the propagation of the information concerning environmental resource-saving and similar thematic issues through the media and other sources;

8) Inclusion of environmental issues in the new educational standards.

It is obvious that the implementation of the above mentioned measures will have a positive syn-ergetic effect in the field of construction environmental safety and sustainable urban develop-ment.

In Russia, state construction companies have been still acting as the main engines of the process but Russian business is gradually starting to take an interest in green construction projects. With the transition of the economy to the intensive model of development and the awareness of the green building benefits, attractiveness of ecological building will grow.

In Russia, several centres for the coordination of the standards of Green building have been created. They are RuGBC (Russian Green Building Council); FSC (Forest Stewardship Council); KEEN GUD (Committee for Real Estate Energy Efficiency and Ecology at the Guild of Man-aging Developers); Non-commercial partnership of the Ministry of Natural Resources and Envi-ronment of the Russian Federation; State Corporation "Olimpstroy"; National Bureau of Russian Envi- 
ronmental Standards and Ratings.

These centres adapt foreign civil engineering standards to the peculiar features of the Russian design and construction industry.

At the same time, the demand for facilities built according to environmental standards is being gradually formed in the real estate market. This is due to the arrival of large international companies at the Russian market; they build facilities in big cities, mainly in Moscow and St. Petersburg. The construction of unique Olimpic facilities in Sochi influenced greatly on the growing popularity of eco-friendly construction.

Several office and residential buildings certified under the international system LEED and BREEAM have been built in recent years in Russia. Ducat Place III, Japanese house, the SIE-MENS Headquarter in Moscow, business centres "Pulkovo Sky", "Alpiyskiy" and "Grecheskiy", technology park "Technopolis Pulkovo" IFC "Aeroportsiti St. Petersburg", residential complexes "Vita Nova", "Trinity", "Swedish krona", "Triumph Park" in St. Petersburg, Skolkovo, "Zavod" in Kimry, etc. are among them.

In particular, a 14-storey business centre Ducat Place III got a certificate "Very Good" according to BREEAM environmental standards. Major modern ecological technologies such as modern system of automation equipment; energy-saving lamps, light sensors and water meters; separate waste collection and sorting are applied in the building. Thanks to these measures, the building energy consumption decreased by almost $35 \%$ compared with previous years.

\section{CONCLUSION}

It is obvious that to increase the number of buildings and facilities that are certified according to the system of National green building standard in the shortest time possible, a serious state economic and social support of the initiators of the construction is necessary. This support should include:
a) Tax deductions for an amount equal to half of the money spent by the investor while imple-menting green construction project;
b) Government grants in the amount of $30-50 \%$ of the cost of green technology
implementation;
c) Promotion of green building among the business community and population through

confer-ences, open tables, television and radio programs.

At this stage of the development of green building in Russia it is important to improve and update the regulatory framework that would meet the modern trends in the implementation of green technologies in construction and operation of buildings and structures. It is necessary to actively create and develop national standards for green construction. Obligatory certification of public buildings according to the national environmental standard should be implemented by the state.

Pilot projects based on green technologies that do not require large investments can lead to active development and implementation of green technologies in construction industry in Russia. Positive results of such practice will increase the range of the technologies and expand the number of companies introducing them as well as attract the attention of the public and political leaders.

\section{REFERENCES}

1) Brown, V.K., Polyakov, A.N. (2011). Environmental award of the Builder. The head of the construction organization, No 1, 14-20.

2) Telichenko, V.I., Potapov, A.D., Slesarev, M.Yu., Shcherbina, E.V. (2009). The ecological safety of construction. Publishing Architecture. Moscow. 311.

3) Nalewaik, A., Venters V. (2008). Costs and Benefits of Green Building. AACE International Transactions. 248-256.

4) Lockwood C. (2006). Building the Green Way. Harvard Business Publishing. 129-135.

5) Singh, A., Syal, M., Grady, S.C., Korkmaz, S. (2010). Effects of Green Buildings on Employ-ee Health and Productivity. Am J Public Health. 1665-1668.

6) Roderick, Y., McEwan, D., Wheatley, C., Alonso, C. (2009). Comparison of energy perfor-mance assessment between LEED, BREEAM and Green Star. Eleventh International IBPSA Conference Building Simulation. 1167-1176.

7) DGNB German Sustainable Building Council (2012). Excellence defined. Sustainable building with a system approach. DGNB $\mathrm{GmbH}, 30$.

8) http://www.usgbc.org/leed\#rating.LEED Rat- 
ing Systems. U.S. Green Building Council 2015 Sep 18.

9) Lee, W.L., Burnett, J. (2008). Benchmarking energy use assessment of HK-BEAM, BREEAM and LEED. Building and Environment. 43. 1882-1891.

10) BRE Environmental \& Sustainability Standard. (2009). BREEAM Europe Commercial
As-sessor Manual, SD 5066A: ISSUE 1.1. 345.

11) Donovan, F. (2009). Our Uncertain Future: Can Good Planning Create Sustainable Com-munities? University of Illinois. 3-7.

Paper sent to revision: 30.07.2017.

Paper ready for publication: 14.09.2017. 